\title{
PEER REVIEW
}

\section{PEER REVIEW PROCESS FOR RESEARCH ARTICLES IN ATZ, MTZ AND ATZ ELEKTRONIK}

STEERING COMMITTEE

\begin{tabular}{|c|c|c|}
\hline Prof. Dr.-Ing. Lutz Eckstein & RWTH Aachen University & $\begin{array}{l}\text { Institut für } \\
\text { Kraftfahrzeuge Aachen }\end{array}$ \\
\hline Prof. Dipl.-Des. Wolfgang Kraus & HAW Hamburg & $\begin{array}{l}\text { Department Fahrzeugtechnik } \\
\text { und Flugzeugbau }\end{array}$ \\
\hline Prof. Dr.-Ing. Ferit Küçükay & $\begin{array}{l}\text { Technische Universität } \\
\text { Braunschweig }\end{array}$ & Institut für Fahrzeugtechnik \\
\hline Prof. Dr.-Ing. Stefan Pischinger & RWTH Aachen University & $\begin{array}{l}\text { Lehrstuhl für } \\
\text { Verbrennungskraftmaschinen }\end{array}$ \\
\hline $\begin{array}{l}\text { Prof. Dr.-Ing. } \\
\text { Hans-Christian Reuss }\end{array}$ & Universität Stuttgart & $\begin{array}{l}\text { Institut für Verbrennungs- } \\
\text { motoren und Kraftfahrwesen }\end{array}$ \\
\hline Prof. Dr.-Ing. Ulrich Spicher & Universität Karlsruhe & Institut für Kolbenmaschinen \\
\hline Prof. Dr.-Ing. Hans Zellbeck & Technische Universität Dresden & $\begin{array}{l}\text { Lehrstuhl für } \\
\text { Verbrennungsmotoren }\end{array}$ \\
\hline
\end{tabular}

\section{ADVISORY BOARD}

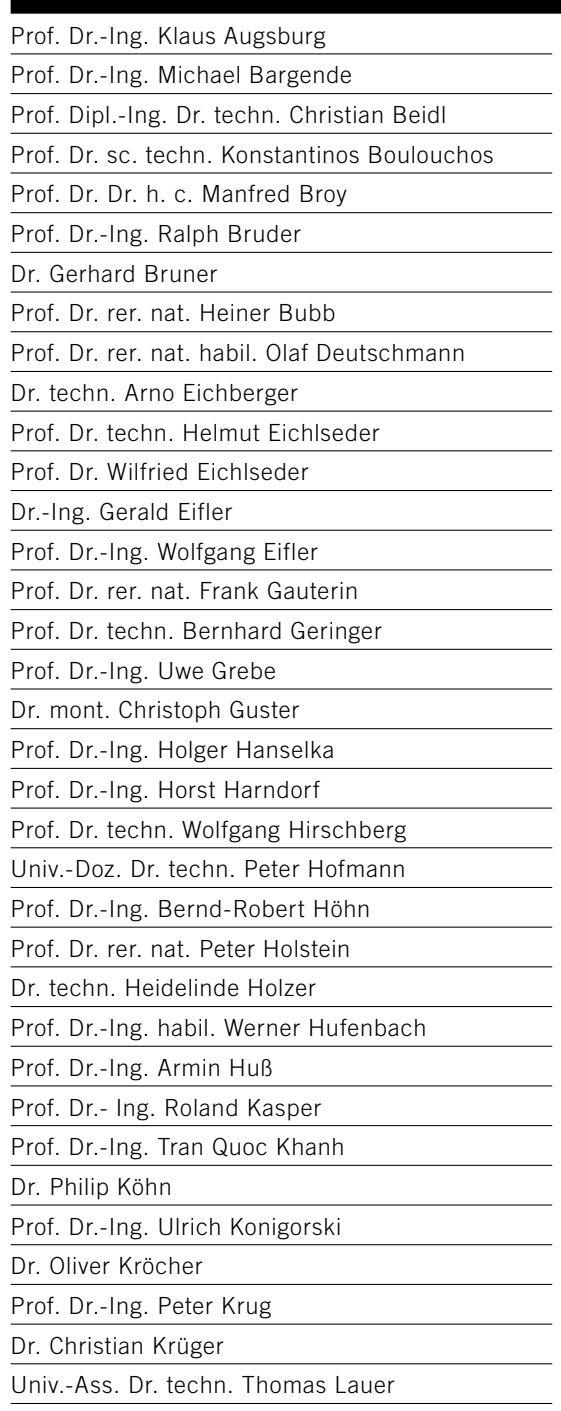

Scientific articles of universities in ATZ Automobiltechnische Zeitschrift, MTZ Motortechnische Zeitschrift and ATZelektronik are subject to a proofing method, the so-called peer review process. Articles accepted by the editors are reviewed by experts from research and industry before publication. For the reader, the peer review process further enhances the quality of the magazines' content on a national and international level. For authors in the institutes, it provides a scientifically recognised publication platform.

In the Peer Review Process, once the editors has received an article, it is reviewed by two experts from the Advisory Board. If these experts do not reach a unanimous agreement, a member of the Steering Committee acts as an arbitrator. Following the experts' recommended corrections and subsequent editing by the author, the article is accepted.

In 2008, the peer review process utilized by ATZ and MTZ was presented by the WKM (Wissenschaftliche Gesellschaft für Kraftfahrzeug- und Motorentechnik e. V./German Professional Association for Automotive and Motor Engineering) to the DFG (Deutsche Forschungsgemeinschaft/German Research Foundation) for official recognition. ATZelektronik participates in the Peer Review since 2011.

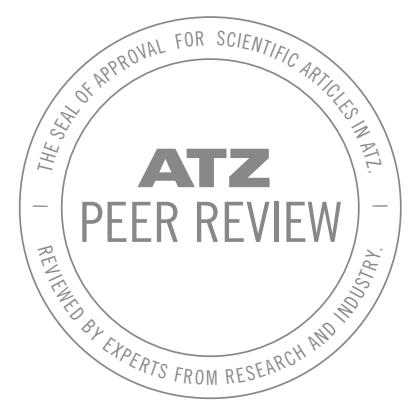

